\title{
Advances in stroke evaluation and treatment
}

\author{
Avanços na avaliação e tratamento do acidente vascular cerebral \\ Flavio Augusto de Carvalho ${ }^{1}$, Gisele Sampaio Silva ${ }^{1}$
}

\begin{abstract}
One of neurology's most challenging and evolving fields, vascular neurology has been constantly calling for attention. From small breakthroughs to large randomized trials, the quest for new answers in stroke treatment has brought us many advances and keeps bringing problems and solutions as new trials are coming.
\end{abstract}

Keywords: Stroke; Neuroimaging; Reperfusion

\section{RESUMO}

A neurologia vascular é uma das áreas mais envolventes e um dos maiores desafios para o neurologista, e tem chamado constantemente a atenção. Desde pequenos estudos revolucionários até grandes ensaios randomizados, a necessidade de novas respostas no tratamento do acidente vascular cerebral tem trazido inúmeros avanços, problemas e soluções conforme novos estudos clínicos são publicados.

Descritores: Acidente vascular cerebral; Neuroimagem; Reperfusão

\section{INTRODUCTION}

\section{Recanalization and reperfusion therapies in acute ischemic stroke}

Succesfull recanalization, the Holy Grail of acute ischemic stroke therapy, is promisingly shown to be possible with several techniques ${ }^{(1)}$. Currently, intravenous thrombolysis with tissue plasminogen activator (rt-PA) in the first 4.5 hours for selected patients remains the standard of care with simultaneous transcranial Doppler ultrasound monitoring being advisable because this method can improve recanalization rates ${ }^{(1-3)}$. However, intra-arterial therapy up to 8 hours after stroke is increasingly being performed for patients whose vessels do not open with intravenous rt-PA or for those who are not eligible for systemic thrombolysis. Devices for mechanical thrombectomy, such as the
MERCI retriever (Concentric Medical, Mountain View, California) and the PENUMBRA System (Penumbra, Alameda, California), provide excellent recanalization rates $^{(4,5)}$. Just recently, the SOLITAIRE device (ev3, Plymouth, Minnesota), a self-expanding stent retriever, was approved by Food and Drug Administration (FDA) for stroke treatment based on the positive results described in the SWIFT trial. The SOLITAIRE device when compared with MERCI, achieved recanalization rates of 83.3 versus $48.1 \%$ ( $p<0.0001)$, respectively, also leading to other better results as lower mortality at 3 months, and lower rates of symptomatic intracranial bleeding ${ }^{(6)}$.

\section{Neuroimaging and stroke}

The use of imaging methods to select patients for late recanalization therapies based on a penumbral pattern of magnetic resonance imaging (MRI) diffusion/ perfusion mismatch is also under scrutiny. Despite negative results, recent trials have drawn the attention to this subject. One is the MR-RESCUE trial, an MRI based trial investigating the benefit of rescue mechanical thrombectomy in patients with diffusion/perfusion mismatch, which currently looks for evidence to this method. This trial has just stopped recruiting patients and its results will be announced in the near future ${ }^{(7)}$.

Other imaging techniques are expected to play a role in the treatment of vascular diseases. Vessel wall imaging is currently being used to differentiate and identify several vascular conditions. Inflammation in atherosclerotic plaques can be identified by both [18F]-2-fluoro-2-deoxy-d-glucose positron emission tomography and MRI techniques ${ }^{(8,9)}$. Vessel wall enhancement on MRI is highly predictive of arterial

'Programa Integrado de Neurologia, Hospital Israelita Albert Einstein - HIAE, São Paulo (SP), Brazil; Department of Neurology and Neurosurgery, Universidade Federal de São Paulo - UNIFESP, São Paulo (SP), Brazil.

Corresponding author: Gisele Sampaio Silva - Avenida Albert Einstein 627, suíte 218 - Morumbi - Zip code: 05652-000 - São Paulo (SP), Brazil - Phone: (55 11) 2151-3340 Email: giselesampaio@hotmail.com

Received on: Mar 23, 2012 - Accepted on: May 7, 2012 
wall inflammation, and can differentiate between cerebral vasoconstriction syndrome and vasculitis ${ }^{(10)}$.

\section{Secondary prevention of ischemic stroke}

If intra-arterial reperfusion therapies are still a matter of debate, secondary prevention with aspirin has been reascertained after the negative results of the PERFORM trial, which tested the selective thromboxaneprostaglandin receptor antagonist terutroban against $\operatorname{aspirin}^{(11)}$. On the other hand, never have we seen so many new possibilities for secondary prevention of stroke thanks to the development of three new oral anticoagulants for patients with nonvalvular atrial fibrillation. The RELY trial compared dabigatran, a direct thrombin inhibitor, with warfarin ${ }^{(12)}$. Similar bleeding rates and lower rates of stroke were observed with $150 \mathrm{mg}$ twice daily of dabigatran.

Recently, apixaban and rivaroxaban, two factor Xa inhibitors, also showed positive results in comparison to warfarin, as observed in the ARISTOTLE and ROCKET AF trials ${ }^{(13,14)}$. One can imagine that we should expect a raise in the number of succesfully treated individuals with the appearance of such options; however, the true impact of the use of those new drugs in the stroke prevention scenario is still to be analyzed.

\section{Treatment of hemorrhagic stroke}

Acute treatment of hemorrhagic stroke is also a promising field in vascular neurology. Not only do we understand better its potential complications (i.e. the spot sign can predict greater chances of hematoma expansion) but also are beginning to treat it better with more aggressive control of hypertension in the acute phase, as suggested to be safe in the INTERACT trial $^{(15)}$. This approach is now under further investigation in the INTERACT 2 trial $^{(16)}$.

In addition, new ways to treat hemorrhagic stroke are coming to light. One is the use of minimally invasive surgery that is being evaluated by the MISTIE trial. Also the CLEAR trial has been evaluating the use of intraventricular rt-PA for clot lysis in intraventricular hemorrhages, what so far appears to be promising ${ }^{(17,18)}$.

\section{CONCLUSIONS}

Evaluation and treatment of stroke has definitely improved over the last years, mostly due to well designed and patient oriented clinical trials. Although several questions remain unanswered, clinicians nowadays are able to manage patients with acute stroke and to conduct secondary stroke prevention using more evidence-based medicine than ever.

A remaining challenge right now is to implement efforts to assure that advances in stroke evaluation and treatment are going to be available for more and more patients, regardless of their geographical location and socio-economic status.

\section{REFERENCES}

1. Adams HP Jr, del Zoppo G, Alberts MJ, Bhatt DL, Brass L, Furlan A, et al. Guidelines for the early management of adults with ischemic stroke: a guideline from the American Heart Association/American Stroke Association Stroke Council, Clinical Cardiology Council, Cardiovascular Radiology and Intervention Council, and the Atherosclerotic Peripheral Vascular Disease and Ouality of Care Outcomes in Research Interdisciplinary Working Groups: The American Academy of Neurology affirms the value of this guideline as an educational tool for neurologists. Circulation. 2007;115(20):e478-534. Erratum in: Circulation. 2007;116(18):e515.

2. Hacke W, Kaste M, Bluhmki E, Brozman M, Dávalos A, Guidetti D, Larrue V Lees KR, Medeghri Z, Machnig T, Schneider D, von Kummer R, Wahlgren N, Toni D; ECASS Investigators. Thrombolysis with alteplase 3 to 4.5 hours after acute ischemic stroke. N Engl J Med. 2008;359(13):1317-29.

3. Alexandrov AV. Ultrasound enhancement of fibrinolysis. Stroke. 2009;40(3 Suppl): S107-10

4. Grunwald IQ, Wakhloo AK, Walter S, Molyneux AJ, Byrne JV, Nagel S, et al. Endovascular stroke treatment today. AJNR Am J Neuroradiol. 2011; 32(2):238-43.

5. Pierot $\mathrm{L}$, van der Bom IM, Wakhloo AK. Advances in stroke: advances in interventional neuroradiology. Stroke. 2012;43(2):310-3

6. SolitaireTM FR with the intention for thrombectomy (SWIFT) study [Internet]. 2012 [cited 2012 Mar 12]. Available from: http://clinicaltrials.gov/ct2/show/ NCT01054560

7. Mechanical retrieval and recanalization of stroke clots using embolectomy (MR RESCUE) [Internet]. 2012 [cited 2012 Mar 12]. Available from: http:// clinicaltrials.gov/ct2/show/NCT00389467

8. Kidwell CS, Heiss WD. Advances in stroke: imaging. Stroke. 2012;43(2):302-4

9. Kwee RM, Truijman MT, Mess WH, Teule GJ, ter Berg JW, Franke CL, et al. Potential of integrated [18F] fluorodeoxyglucose positron-emission tomography/ct in identifying vulnerable carotid plaques. AJNR Am J Neuroradiol. 2011;32(5):950-4.

10. Mandell DM, Matouk CC, Farb RI, Krings T, Agid R, terBrugge K, et al. Vessel wall $\mathrm{MRI}$ to differentiate between reversible cerebral vasoconstriction syndrome and central nervous system vasculitis: preliminary results. Stroke. 2012;43(3):860-2.

11. Bousser MG, Amarenco P, Chamorro A, Fisher M, Ford I, Fox KM, Hennerici MG, Mattle HP, Rothwell PM, de Cordoüe A, Fratacci MD; PERFORM Study Investigators. Terutroban versus aspirin in patients with cerebral ischaemic events (PERFORM): a randomised, double-blind, parallel-group trial. Lancet. 2011;377(9782):2013-22.

12. Connolly SJ, Ezekowitz MD, Yusuf S, Eikelboom J, Oldgren J, Parekh A, Pogue J, Reilly PA, Themeles E, Varrone J, Wang S, Alings M, Xavier D, Zhu J, Diaz R, Lewis BS, Darius H, Diener HC, Joyner CD, Wallentin L; RE-LY Steering Committee and Investigators. Dabigatran versus warfarin in patients with atrial fibrillation. N Engl J Med. 2009;361(12):1139-51.

13. Granger CB, Alexander JH, McMurray JJ, Lopes RD, Hylek EM, Hanna M, Al-Khalidi HR, Ansell J, Atar D, Avezum A, Bahit MC, Diaz R, Easton JD, Ezekowitz JA, Flaker G, Garcia D, Geraldes M, Gersh BJ, Golitsyn S, Goto S, Hermosillo AG, Hohnloser SH, Horowitz J, Mohan P, Jansky P, Lewis BS, Lopez-Sendon JL, Pais P, Parkhomenko A, Verheugt FW, Zhu J, Wallentin L; ARISTOTLE Committees and Investigators. Apixaban versus warfarin in patients with atrial fibrillation. N Engl J Med. 2011;365(11):981-92. 
14. Patel MR, Mahaffey KW, Garg J, Pan G, Singer DE, Hacke W, Breithardt G, Halperin JL, Hankey GJ, Piccini JP, Becker RC, Nessel CC, Paolini JF, Berkowitz SD, Fox KA, Califf RM; ROCKET AF Investigators. Rivaroxaban versus warfarin in nonvalvular atrial fibrillation. N Engl J Med. 2011;365(10):883-91.

15. Anderson CS, Huang $Y$, Arima $H$, Heeley E, Skulina C, Parsons MW, Peng B, Li O, Su S, Tao OL, Li YC, Jiang JD, Tai LW, Zhang JL, Xu E, Cheng Y, Morgenstern LB, Chalmers J, Wang JG; INTERACT Investigators. Effects of early intensive blood pressure-lowering treatment on the growth of hematoma and perihematomal edema in acute intracerebral hemorrhage: The Intensive Blood Pressure Reduction in Acute Cerebral Haemorrhage Trial (INTERACT). Stroke. 2010;41(2):307-12.
16. Delcourt C, Huang Y, Wang J, Heeley E, Lindley R, Stapf C, Tzourio C, Arima H, Parsons M, Sun J, Neal B, Chalmers J, Anderson C; INTERACT2 Investigators. The second (main) phase of an open, randomised, multicentre study to investigate the effectiveness of an intensive blood pressure reduction in acute cerebral haemorrhage trial (INTERACT2). Int J Stroke. 2010;5(2):110-6.

17. Morgan T, Zuccarello M, Narayan R, Keyl P, Lane K, Hanley D. Preliminary findings of the minimally-invasive surgery plus rtPA for intracerebral hemorrhage evacuation (MISTIE) clinical trial. Acta Neurochir Suppl. 2008; 105:147-51.

18. Morgan T, Awad I, Keyl P, Lane K, Hanley D. Preliminary report of the clot lysis evaluating accelerated resolution of intraventricular hemorrhage (CLEAR-IVH) clinical trial. Acta Neurochir Suppl. 2008;105:217-20. 